\title{
THE POSSIBILITIES OF OWN BLOCKS IN THE SCRATCH EDUCATIONAL ENVIRONMENT*
}

\section{KRASIMIR V. HARIZANOV}

\begin{abstract}
In the present study, the main possibilities of own block in Scratch block environment are considered. An example implementation is proposed, which can be used in the curriculum of the discipline "Computer Modeling and Information Technology". Some peculiarities related to the application of own blocks in the creation of animations, algorithms and educational projects in the Scratch block environment are presented.
\end{abstract}

KEYWORDS: computer modelling; game-based learning; Scratch; $e$ learning; interactive education

2020 Math. Subject Classification: 97P20 u 97B20

\section{Introduction}

With the introduction of the new curricula in Computer Modeling and Information Technology for grades 5-7 in 2021, the new global topic "Computer Modeling" was introduced, a natural continuation of the discipline "Computer Modeling" studied in 3rd and 4th grade. This module develops students' knowledge by confronting them with new challenges, such as "educational project scenario", "animation of computer characters with subroutines", "improving existing projects using their own blocks or subroutines" [3]. These new possibilities related to block programming are the first stage of the ones set in the curricula (grades 5-7), transition from a block programming language to a script text language. According to some authors, "the process of forming algorithmic thinking and digital creativity in students should begin in primary school and be upgraded and developed in each subsequent stage of learning." [1].

*This article was supported in part by a project РД-08-111/02.02.2021 
In order to form the main competencies of students and skillfully apply them in practical tasks, it is necessary for teachers to use different methods and approaches for their mastering. According to various studies, methods of scientific knowledge, such as comparison, analysis and synthesis "contribute to more effective learning, as well as to the development of the student's personality." [2]. Some of these methods are related to building computer skills, while others are related to practical training aimed at the future teaching of scripting text language.

\section{Example of using own blocks in a Scratch environment}

The article discusses an example in which different types of own blocks are used, offered in the Scratch block environment. The example is a Christmas star task that needs to be decomposed into several sub-programs. The main character in the task must draw two star patterns. A basic can be draws ten times in random places on the stage and one to be draws on top of the Christmas tree.

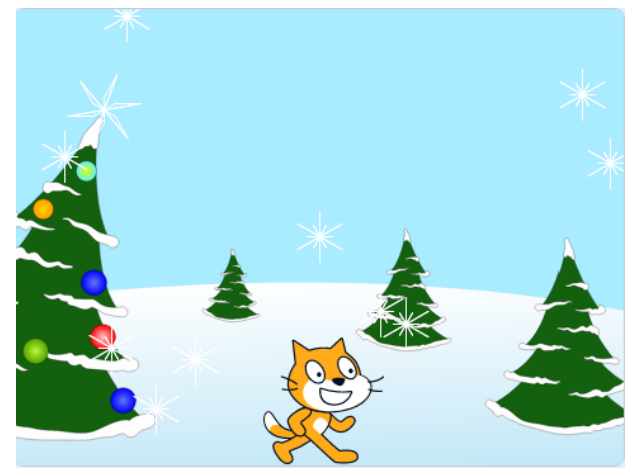

Figure 1. Visual solution of the task

In creating this task, the following steps can be followed:

\section{Stage 1}

Decompose the main code of the task into separate logical areas. At this stage it is necessary to comment on what are the 
repetitive actions and how they can be separated into self-executable code.

\section{Stage 2}

Create your own block with a parameter. Here it is argued the need to use the blocks to enter a value from the keyboard, which will serve as a block with a parameter when drawing the individual rays of the star. The first star should be drawn in the middle of the scene with coordinates $\mathrm{x}$ : $0 ; \mathrm{y}$ : 0 . It is desirable that the name of the own block be with a small name, as it will be introduced in the future scripting text programming language.

\section{Stage 3}

Creating your own block with a logical condition and labels to it. This block creates the star on the Christmas tree. The two parameters and the labels to them determine the position for drawing the star, and the condition checks whether it is drawn. And here the "name of your own block should be with a small name" [4].

\section{Stage 4}

At the end of the implementation, the initial volume of the blocks is compared and how they have been optimized since then. Attention is paid to the created subroutines, their names and the ability to be called and executed repeatedly within the program. It is important to note that own blocks can be used only in the sprite to which they are created. 


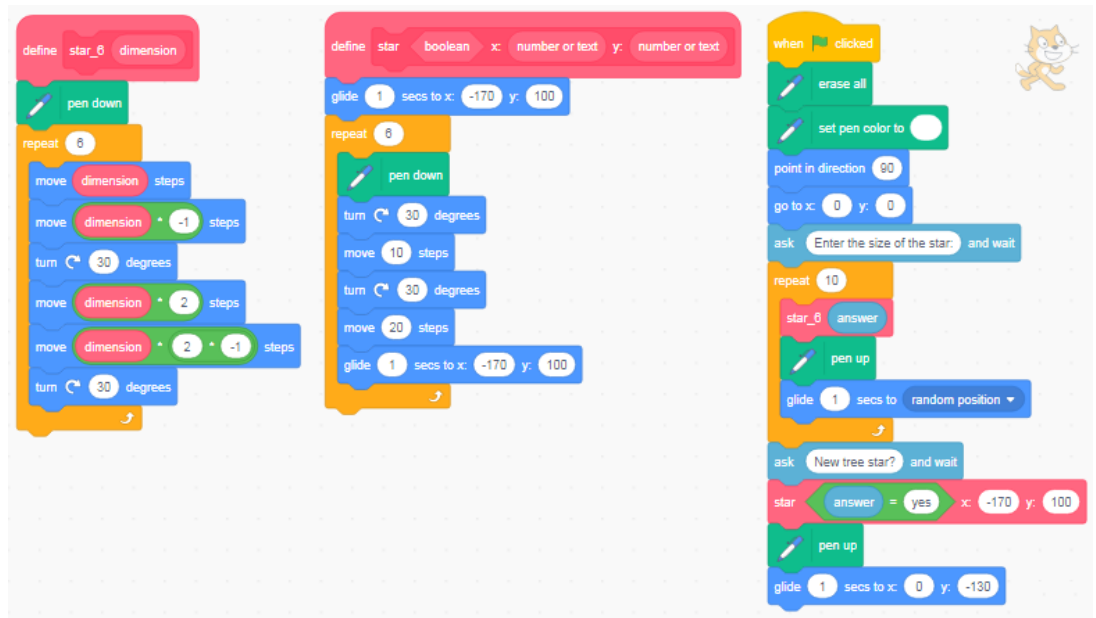

Figure 2 Code solution of the task

\section{Conclusion}

Building algorithmic thinking, through the use of a block environment, makes it possible to build a lasting foundation of knowledge to be used in the coming years of study. Creating your own blocks to be applied as subroutines or functions in solving practical tasks contributes to the easier and natural transition from block programming to scripting text programming.

\section{REFERENCES:}

[1] Анева, С., Е. Тодорова. Възможности за развитие на алгоритмични умения на учениците в обучението по предмета „компютърно моделиране и информационни технологии“" в прогимназията, Юбилейна международна научна конференция „Компютьрни технологии и приложения“, 15-17 септември 2021 г., Пампорово, България, стр. 37-46.

[2] Тодорова, Е., С. Анева, С. Чиликова, П. Делчева. Формиране и развитие на познавателни умения в обучението по „компютърно моделиране и информационни технологии“ в прогимназията, 
Юбилейна международна научна конференция „Компютьрни технологии и приложения“, 15-17 септември 2021 г., Пампорово, България, стр. 103-144.

[3] URL: https://mon.bg/bg/100884/UP_PC-modelirane-5kl.pdf, достьпно на 02.12.2021 г.

[4] URL:https://bg.izzi.digital/DOS/128034/128054.html?_ga=2.115604294 .1559516161.1640533516-1146790868.1633672642/Bulvest_KM5.pdf, достъпно на 02.12.2021 г.

\section{Krasimir V. Harizanov}

Faculty of Mathematics and Informatics, Shumen University,

Universitetska str. 115, 9700 Shumen, Bulgaria

e-mail: kr.harizanov@shu.bg 